\title{
Aplikasi Pengenalan Rumah Adat Indonesia Berbasis Augmented Reality
}

\author{
Ni Komang Sutiari, I Ketut Gede Darma Putra, I Made Sunia Raharja \\ Program Studi Teknologi Informasi, Fakultas Teknik, Universitas Udayana \\ Bukit Jimbaran, Bali, Indonesia Telp. (0361) 701806 \\ e-mail: sutiari3424@gmail.com, ikgdarmaputra@unud.ac.id, sunia.raharia@unud.ac.id
}

\begin{abstract}
Abstrak
Rumah adat adalah rumah yang memiliki ciri khas bangunan yang melambangkan kebudayaan dari suatu daerah. Keunikan rumah-rumah adat di Indonesia menjadi salah satu materi pembelajaran. Buku-buku yang menjadi media pembelajaran rumah adat memiliki kekurangan berupa terbatasnya tampilan rumah adat secara visual. Penerapan teknologi augmented reality pada media pembelajaran rumah adat bertujuan untuk memberikan informasi yang lebih menarik, naratif, dan informatif. Rumah adat divisualisasikan melalui objek 3-dimensi di dalam aplikasi Android. Aplikasi augmented reality yang dikembangkan bersifat dinamis, sehingga penambahan konten dapat dilakukan tanpa memodifikasi kode program. Aplikasi berhasil memvisualisasikan 6 rumah adat dari 6 provinsi di Indonesia, yaitu rumah adat Provinsi Bali, Papua, Banten, Lampung, Sumatera Barat dan Aceh. Aplikasi memiliki 4 scene yaitu Main Menu, Mulai, Panduan dan Tentang, serta 4 fitur yaitu Info, Rotate, Scale, dan Share. Hasil pengujian menunjukkan aplikasi dapat menampilkan objek 3-dimensi rumah adat dengan melakukan tracking marker pada gambar 2-dimensi.
\end{abstract}

Kata Kunci: Augmented reality, Dinamis, Rumah Adat, Indonesia

\begin{abstract}
The traditional house is a house-building with unique characteristics which symbolize cultures of a local region. Characteristic of a traditional house in Indonesia become a common learning in textbooks. Books as the learning media having some limitation in visualizing the traditional house. The application of augmented reality for learning media of traditional houses aims to provide a more interactive, narrative, and informative learning media. Traditional houses were visualized through 3-dimension objects in an Android application. The developed augmented reality app was dynamic, therefore contents could be added without modifying the source codes. The application succeeded in order to visualize 6 traditional houses from 6 provinces in Indonesia, that was Bali, Papua, Banten, Lampung, West Sumatera and Aceh province. The application consists of 4 scenes, those were Main Menu, Mulai, Panduan, and Tentang, also 4 features namely Info, Rotate, Scale, and Share. Experiment results showed that the application could display 3-dimensional objects of a traditional house by tracking markers on the 2-dimensional images.
\end{abstract}

Keywords: Augmented reality, Dynamic, Traditional House, Indonesia

\section{Pendahuluan}

Indonesia merupakan negara kepulauan dengan berbagai komunitas masyarakat, budaya, dan seni dengan ciri khas berbeda. Pluralisme komunitas masyarakat menciptakan berbagai seni dan kebudayaan yang menunjukkan ciri khas di tiap daerah dengan berbagai macam rumah adat di Indonesia [1].

Rumah adat adalah rumah yang memiliki ciri khas bangunan suatu daerah di Indonesia yang melambangkan kebudayaan suatu daerah [2]. Indonesia memiliki 35 rumah adat yang tersebar dari Sabang sampai Merauke. Masing-masing rumah adat memiliki keunikan yang sesuai dengan kearifan lokal daerah. Keunikan rumah-rumah adat di Indonesia menjadi salah satu materi pembelajaran yang ada di buku-buku pelajaran. Pembelajaran mengenai rumah adat pada media buku teks dengan informasi berupa gambar dan daerah asal rumah adat memiliki kekurangan berupa terbatasnya tampilan rumah adat secara visual, karena buku hanya bisa menampilkan gambar 2-dimensi. Kekurangan media pembelajaran konvensional 
dapat diatasi melalui pemanfaatan teknologi augmented reality. Augmented reality merupakan teknologi yang dapat memproyeksikan benda-benda virtual ke dalam lingkungan dan waktu nyata [3]. AR dapat memvisualisasikan rumah adat menjadi sebuah animasi 3-dimensi informatif dan naratif, sehingga rumah adat bisa ditampilkan secara menyeluruh.

Penelitian tentang teknologi augmented reality telah dilakukan sebelumnya oleh peneliti bernama Pangestu dkk [4] pada tahun 2017 dengan judul penelitian "Aplikasi Web Augmented Reality Villa". Pangestu dkk membangun aplikasi augmented reality berbasis web untuk memvisualisasikan hunian villa melalui scanning brosur sebagai marker. Pemanfaatan teknologi augmented reality yang diterapkan pada smartphone Android dilakukan oleh peneliti bernama Waruwu dkk [5] dengan judul "Augmented Reality Mobile Application of Balinese Hindu Temples: DewataAR", yang dimanfaatkan untuk mempromosikan obyek wisata Pura Tanah Lot di Pulau Bali. Penerapan augmented reality pada smartphone Android juga digunakan sebagai media pembelajaran pengenalan binatang untuk siswa TK oleh peneliti bernama Dhiyatmika dkk [6]. Penelitian-penelitian yang disebutkan masih menerapkan AR statis, sehingga setiap penambahan konten menyebabkan kode program harus dimodifikasi.

Penelitian dengan judul "Aplikasi Pengenalan Rumah Adat Indonesia Berbasis Augmented Reality" ini menerapkan augmented reality untuk memvisualisasikan rumah adat di Indonesia. Aplikasi bernama ARRumahAdat yang dikembangkan bersifat dinamis, sehingga penambahan konten dapat dilakukan tanpa memodifikasi kode program. Output dari Aplikasi ARRumahAdat adalah informasi rumah adat dalam bentuk 3-dimensi dan informasi berupa teks dari rumah adat. Aplikasi ARRumahAdat diharapkan mampu memberikan informasi yang lebih menarik dan dapat melestarikan bangunan rumah adat sebagai warisan budaya Indonesia.

\section{Metodologi Penelitian}

Aplikasi ARRumahAdat merupakan sebuah aplikasi yang diimplementasikan pada platform Andorid untuk memperkenalkan berbagai macam rumah adat yang terdapat di Indonesia. Gambar 1 menunjukkan alur sistem secara umum pada Aplikasi ARRumahAdat.

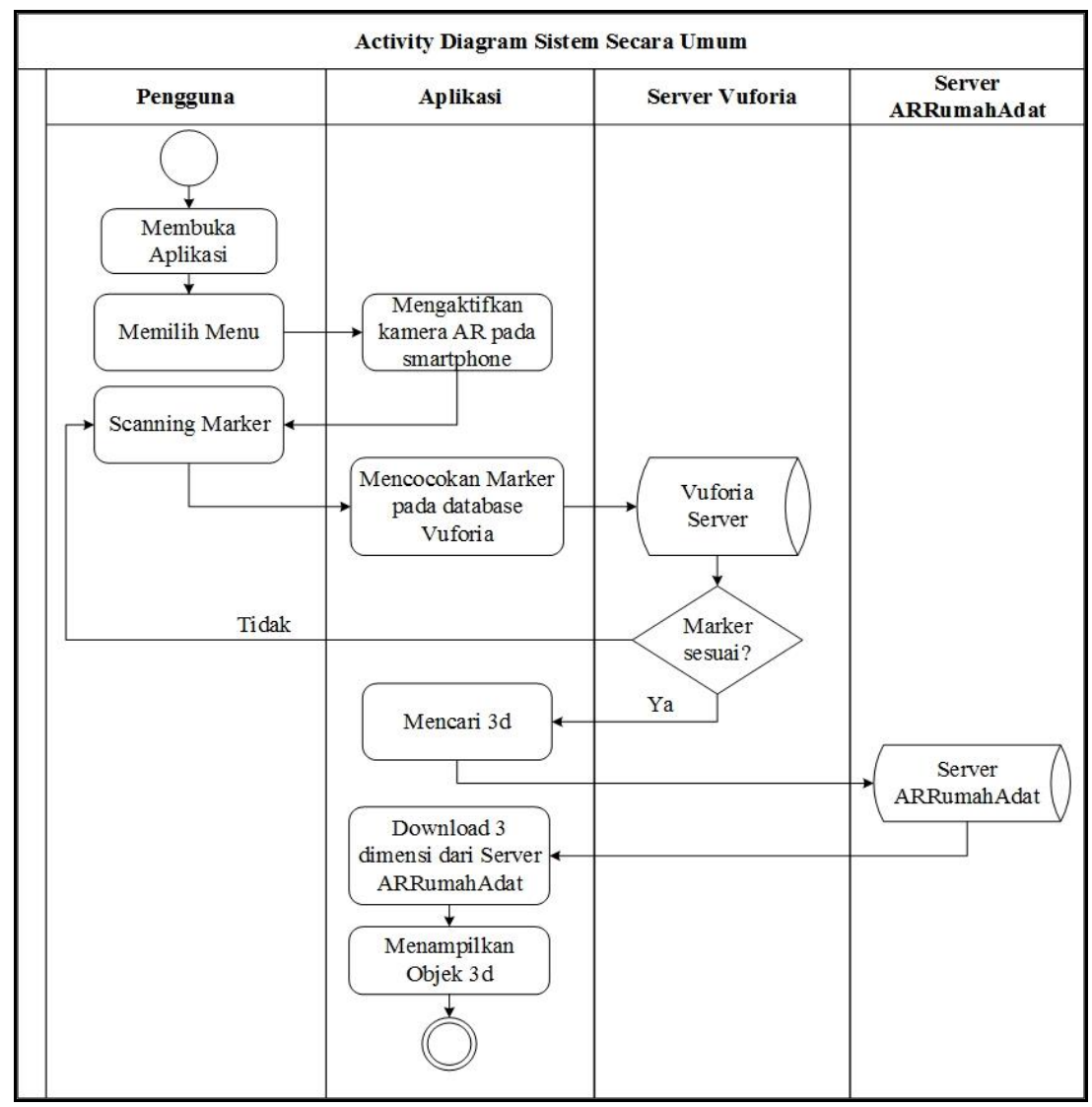

Gambar 1. Alur Sistem ARRumahAdat 
Gambar 1 menunjukkan alur sistem Aplikasi ARRumahAdat dengan mencocokan marker pada database Vuforia, kemudian aplikasi melakukan pencarian objek 3-dimensi yang sesuai dengan marker pada Server ARRumahAdat dan melakukan download objek 3-dimensi yang ditampilkan pada layar smartphone.

\section{Kajian Pustaka}

\subsection{Augmented reality}

Augmented reality (AR) merupakan teknologi yang menggabungkan benda maya 2dimensi dan 3-dimensi ke dalam sebuah lingkungan nyata. Benda-benda maya diproyeksikan dalam waktu nyata, sehingga dapat dilihat secara real-time [7]. Augmented reality hanya menambahkan atau melengkapi kenyataan, tidak seperti virtual reality yang sepenuhnya menggantikan kenyataan [8]. Augmented reality merupakan teknologi yang potensial untuk dikembangkan di berbagai aspek kehidupan. AR dapat digunakan untuk memvisualisasikan objek-objek di dunia nyata agar terlihat lebih menarik, interaktif dan informatif.

\subsection{Rumah Adat}

Rumah adat adalah rumah khas dari berbagai suku di Indonesia yang merupakan warisan budaya yang sangat berharga [9]. Rumah adat mencerminkan salah satu ekspresi budaya dari sekelompok masyarakat. Rumah adat di seluruh wilayah Indonesia memiliki keunikan dengan mencerminkan ciri khas suatu daerah. Keberagaman 35 rumah adat di Indonesia menunjukkan pluralisme budaya di masing-masing pulau yang terbentang dari Sabang sampai Merauke. Rumah adat bukan sekedar bangunan, melainkan sebuah institusi yang diciptakan untuk kompleksitas tujuan hidup. Rumah adat mengekspresikan semangat dan jiwa yang terkandung di dalam masyarakat. Ekspresi semangat dan jiwa masyarakat menyebabkan bentuk dan organisasi rumah adat dipengaruhi oleh budaya yang melatarbelakanginya [10].

\section{3. $\quad$ Marker Based Tracking}

Marker based tracking adalah AR yang bekerja dengan menggunakan marker atau penanda objek 2-dimensi yang memiliki suatu pola dan dibaca komputer melalui kamera. Marker yang digunakan harus memiliki banyak pola dan warna yang kontras sehingga menghasilkan banyak fitur dengan rating tinggi yang mudah dideteksi oleh device [11].

\section{Hasil dan Pembahasan}

Hasil dan pembahasan merupakan bagian untuk menjelaskan mengenai aplikasi yang dihasilkan berdasarkan rancangan aplikasi.

\subsection{Gambaran Umum Aplikasi}

Aplikasi augmented reality yang dikembangkan bernama ARRumahAdat. Aplikasi diperuntukan bagi siswa dan masyarakat umum yang ingin mempelajari rumah adat di Indonesia. ARRumahAdat memberikan pengenalan secara dinamis, sehingga aplikasi dapat berjalan dan menerima penambahan konten secara berkelanjutan tanpa melakukan modifikasi kode program.

Aplikasi ARRumahAdat berjalan pada sistem operasi minimal Android 4.1.2 (Jelly Bean). Pengguna yang ingin menjalankan ARRumahAdat dapat melakukan instalasi berkas .apk di smartphone dan menyiapkan marker rumah adat yang telah ditentukan. Kamera smartphone dapat diarahkan ke marker sehingga objek 3-dimensi muncul pada layar. Keluaran dari Aplikasi ARRumahAdat adalah informasi bangunan rumah adat yang ditampilkan dalam bentuk objek 3-dimensi. 


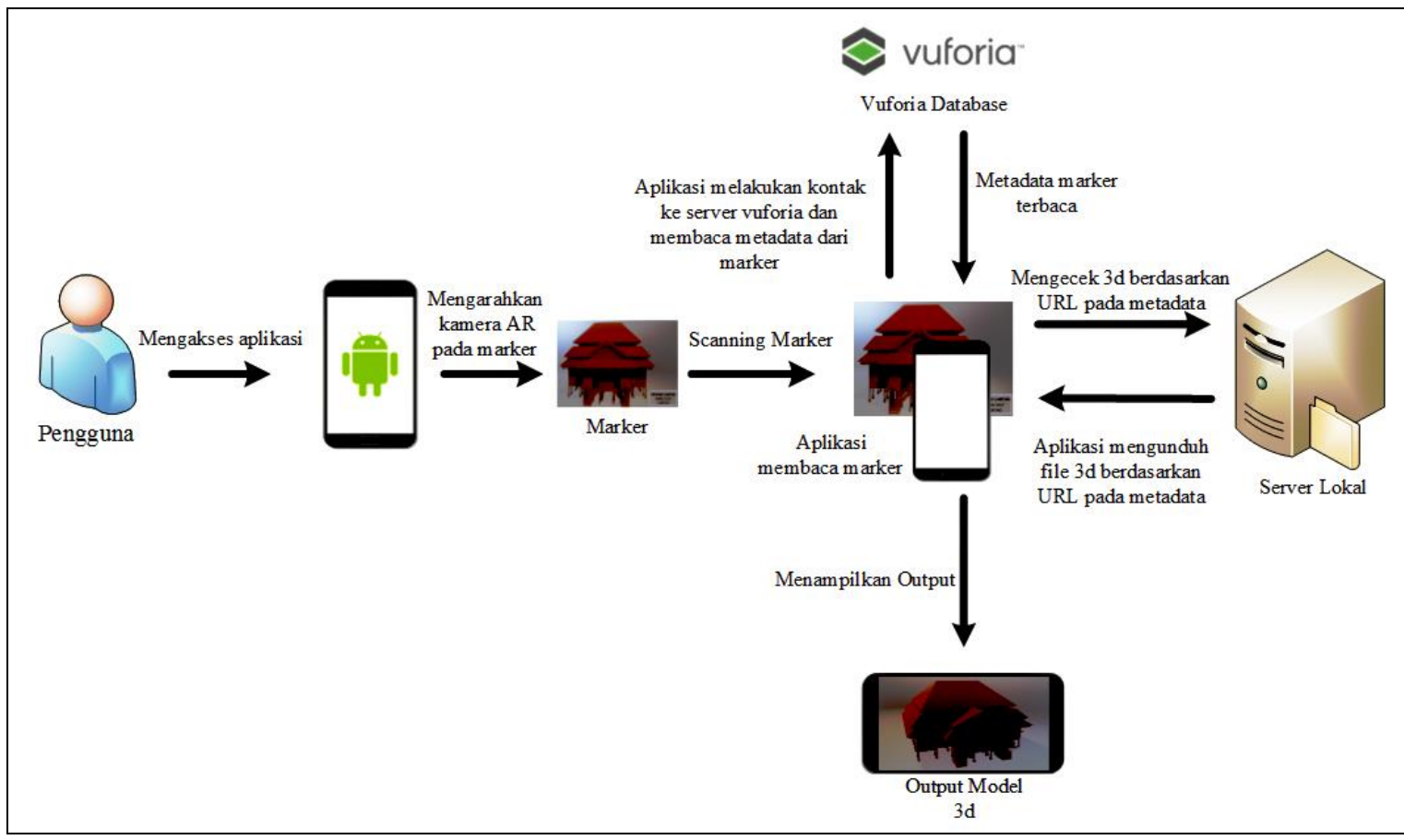

Gambar 2. Gambaran Umum Aplikasi

Gambar 2 merupakan gambaran umum Aplikasi ARRumahAdat yang berjalan di cloud, sehingga diperlukan internet dan XAMPP untuk menghubungkan aplikasi dengan marker dan objek 3-dimensi. Marker dan metadata disimpan pada Server Vuforia, sehingga konten dapat ditambah atau dikurangi tanpa memodifikasi kode program. Metadata marker yang tersimpan di Vuforia berupa alamat IP, lokasi objek 3-dimensi dan informasi setiap objek bangunan 3dimensi masing-masing rumah adat.

\subsection{Objek 3-dimensi dan Scene Aplikasi}

Rumah adat pada Aplikasi ARRumahAdat divisualisasikan dengan objek 3-dimensi. Tabel 1 menunjukkan objek 3-dimensi dari 6 rumah adat yaitu rumah adat Provinsi Bali, Papua, Banten, Lampung, Sumatera Barat dan Aceh.

Tabel 1. Objek 3-dimensi Rumah Adat

\begin{tabular}{|l|l|}
\hline Objek 3-dimensi & \multicolumn{1}{|c|}{ Keterangan } \\
\hline
\end{tabular}




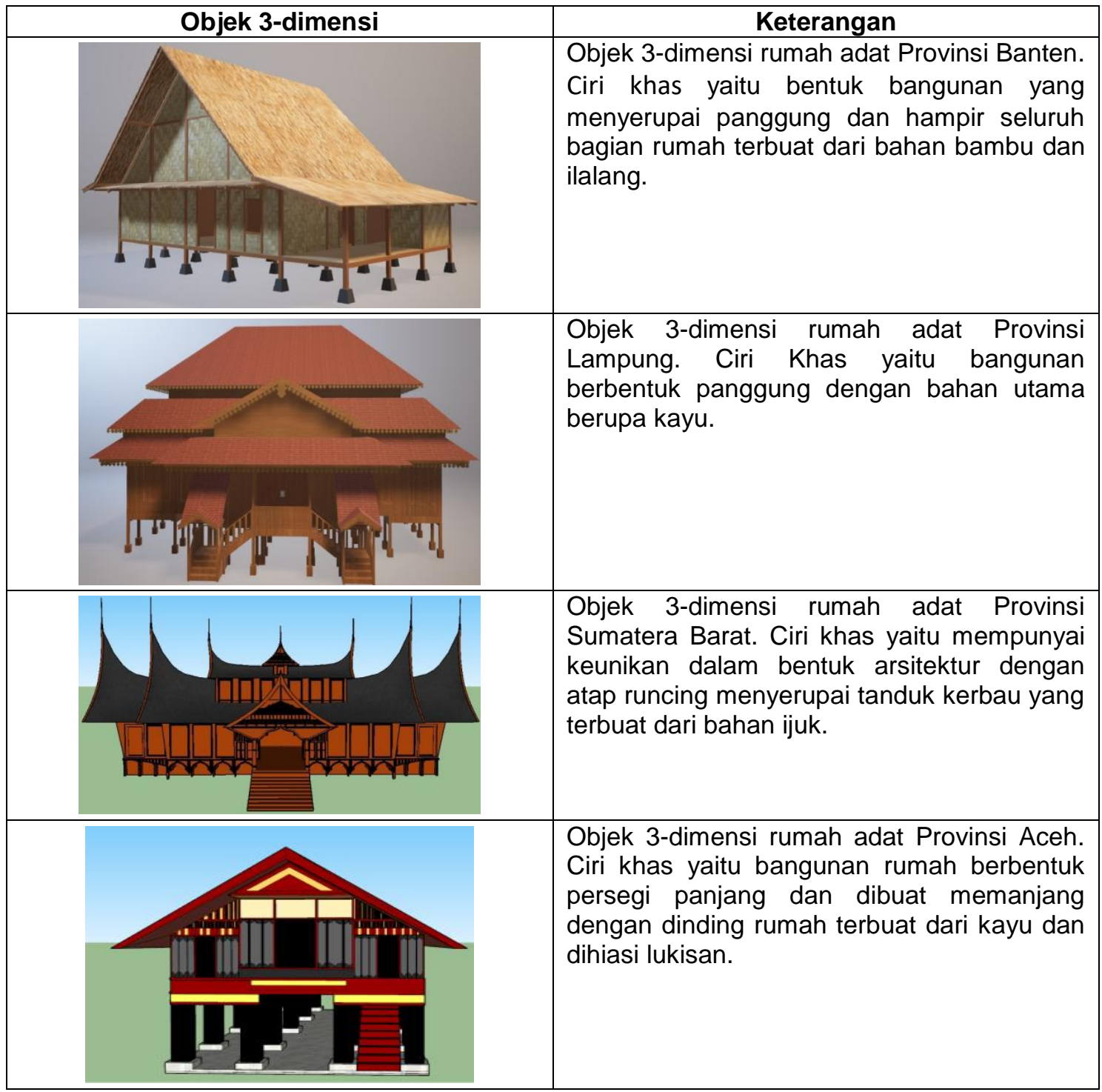

Objek 3-dimensi pada Tabel 1 ditampilkan sebagai visualisasi rumah adat di masingmasing provinsi. Objek 3-dimensi tersebut tersimpan sebagai target di target manager Server Vuforia. Masing-masing target memiliki fitur unik (features) yang dikenali pada proses Tracking Marker. Target manager Aplikasi ARRumahAdat ditunjukkan pada Gambar 3.

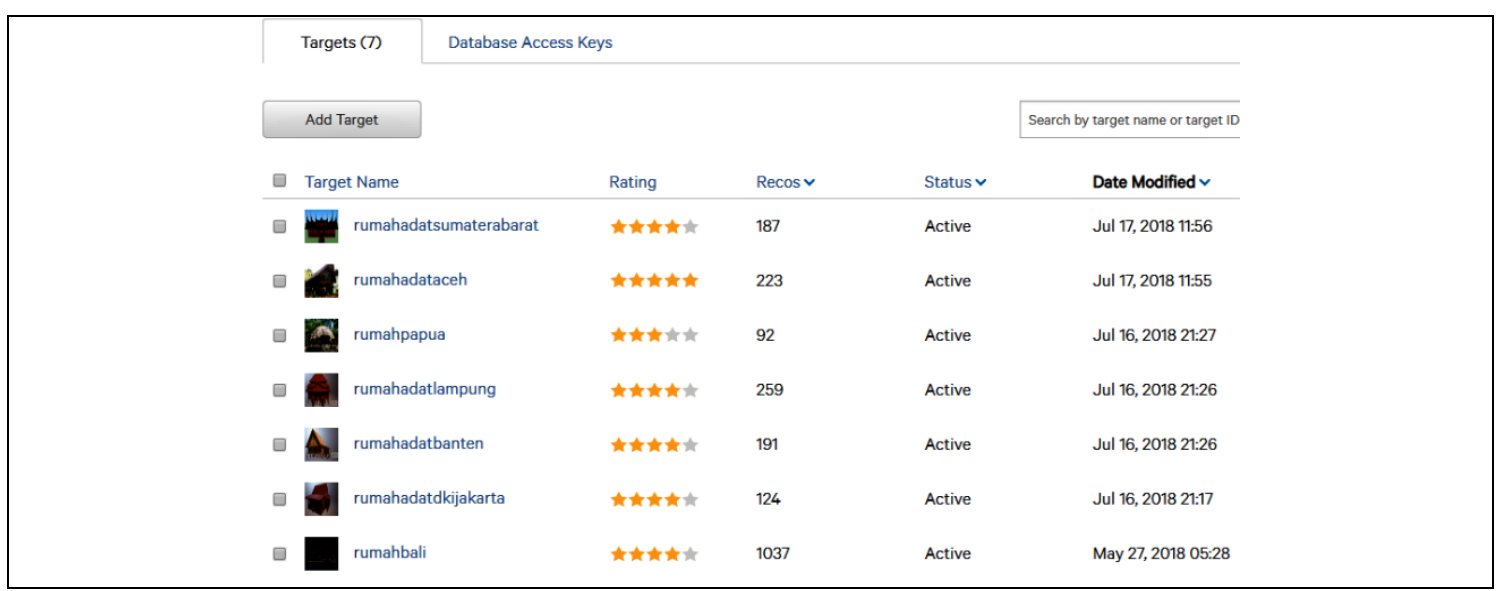

Gambar 3. Target Manager Aplikasi 
Gambar 3 menunjukkan jumlah rating dan recos pada target. Rating pada daftar target menunjukkan jumlah fitur yang dapat dikenali. Recos menunjukkan jumlah pendeteksian yang dilakukan pada target.

Aplikasi memiliki 4 buah scene, yaitu bernama Main Menu, Mulai, Panduan dan Tentang. Tampilan masing-masing scene ditunjukkan pada Tabel 2.

Tabel 2. Scene pada Aplikasi ARRumahAdat

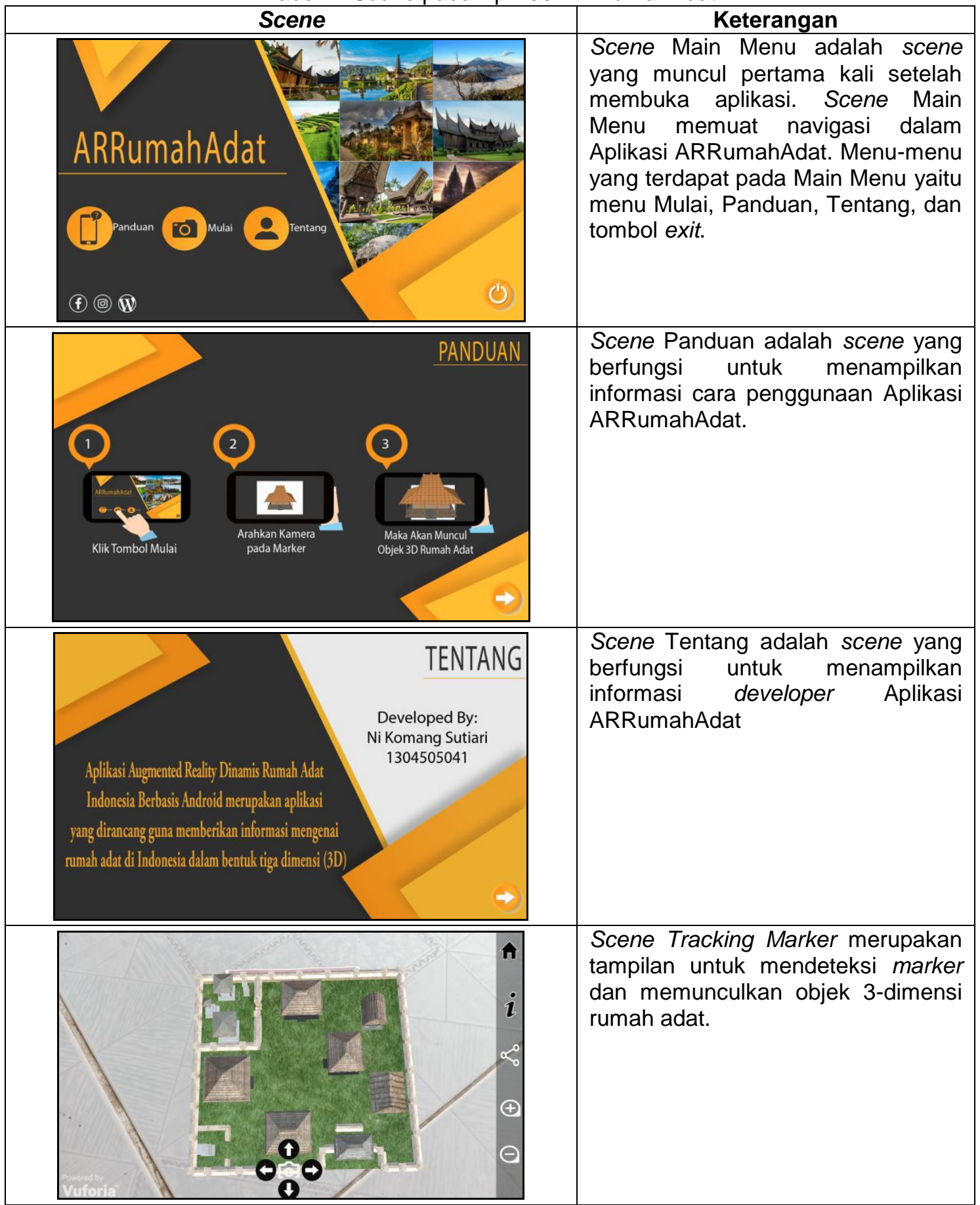

Scene Tracking Marker pada aplikasi menyediakan 4 fitur yang dapat digunakan. Keempat fitur tersebut adalah Info, Rotate, Scale, dan Share. Info adalah fitur yang menampilkan informasi berkaitan dengan objek 3-dimensi yang muncul. Fitur Rotate berfungsi untuk melakukan rotasi ke arah kanan, kiri, atas, dan bawah pada objek 3-dimensi. Scale 
merupakan fitur untuk memperbesar atau memperkecil ukuran objek 3-dimensi. Fitur Share berfungsi untuk membagikan capture objek 3-dimensi yang muncul pada saat dilakukan Tracking Marker ke media sosial.

\subsection{Uji Coba Aplikasi}

Pengujian aplikasi dilakukan untuk mengetahui kinerja aplikasi pada perangkat smartphone. Pengujian Aplikasi ARRumahAdat menggunakan dua buah smartphone Android yaitu Samsung Galaxy Grand Duos dan Samsung Galaxy J3. Spesifikasi perangkat uji coba ditunjukkan pada Tabel 3.

Tabel 3. Spesifikasi Perangkat Uji Coba

\begin{tabular}{|l|l|l|}
\hline Nama Perangkat & Samsung Galaxy Grand Duos & \multicolumn{1}{c|}{ Samsung Galaxy J3 } \\
\hline Sistem Operasi & Android 4.1.2 (Jelly Bean) & Android 6.0 (Marshmallow) \\
\hline Processor & Dual-core 1.2 GHz Cortex-A9 & Quad-core 1.5 GHz Cortex-A7 \\
\hline RAM & $1 \mathrm{~GB}$ & 2GB \\
\hline Display Resolution & $480 \times 800$ piksel & $720 \times 1280$ piksel \\
\hline
\end{tabular}

Komponen-komponen yang diuji dari aplikasi adalah scene dan fitur aplikasi. Scene dan fitur diujicobakan pada kedua perangkat untuk melihat apakah scene dan fitur dapat berfungsi. Dua perangkat uji coba memiliki spesifikasi yang berbeda untuk menilai aplikasi pada dua lingkungan uji coba yang berbeda.

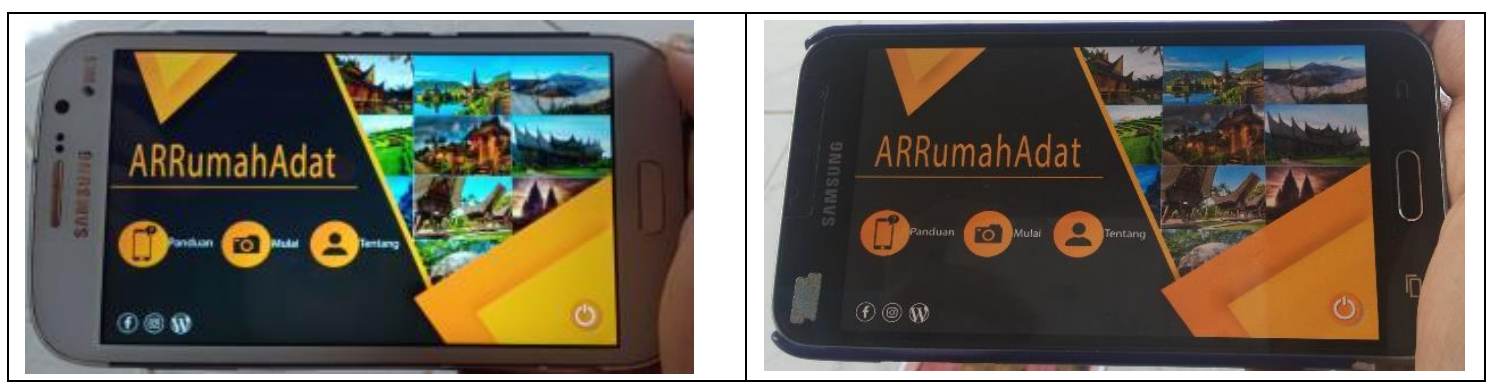

Gambar 4. Uji Coba Main Menu

Gambar 4 menunjukkan scene dapat dioperasikan di kedua perangkat uji coba. Ukuran scene menyesuaikan ukuran kedua layar perangkat. Posisi gambar dan ikon scene muncul secara proporsional.

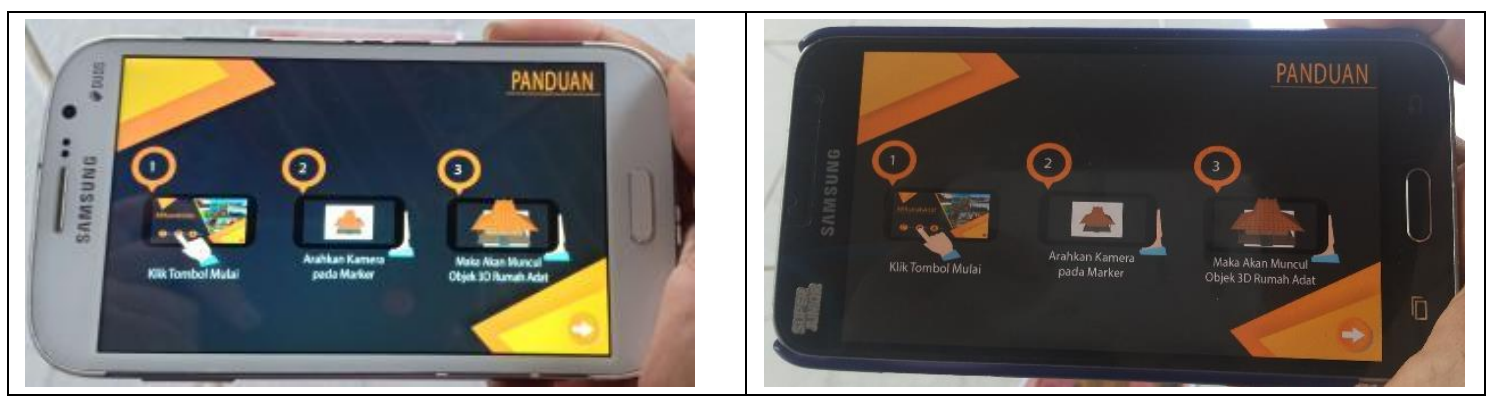

Gambar 5. Uji Coba Scene Panduan

Uji coba pada Gambar 5 menunjukkan Scene Panduan dapat dioperasikan di kedua perangkat uji coba. Posisi gambar dan ikon scene muncul secara proporsional serta ukuran scene menyesuaikan ukuran kedua layar perangkat. 


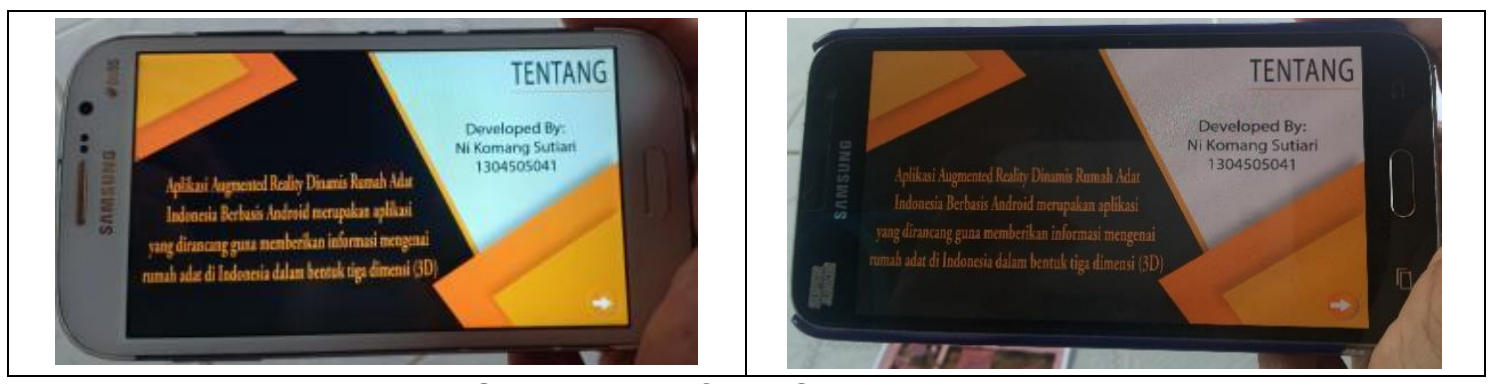

Gambar 6. Uji Coba Scene Tentang

Scene Tentang yang diujicobakan pada Gambar 6 terlihat dapat dioperasikan di kedua perangkat uji coba. Gambar dan ikon pada scene muncul secara proporsional dan ukuran scene menyesuaikan ukuran kedua layar perangkat.

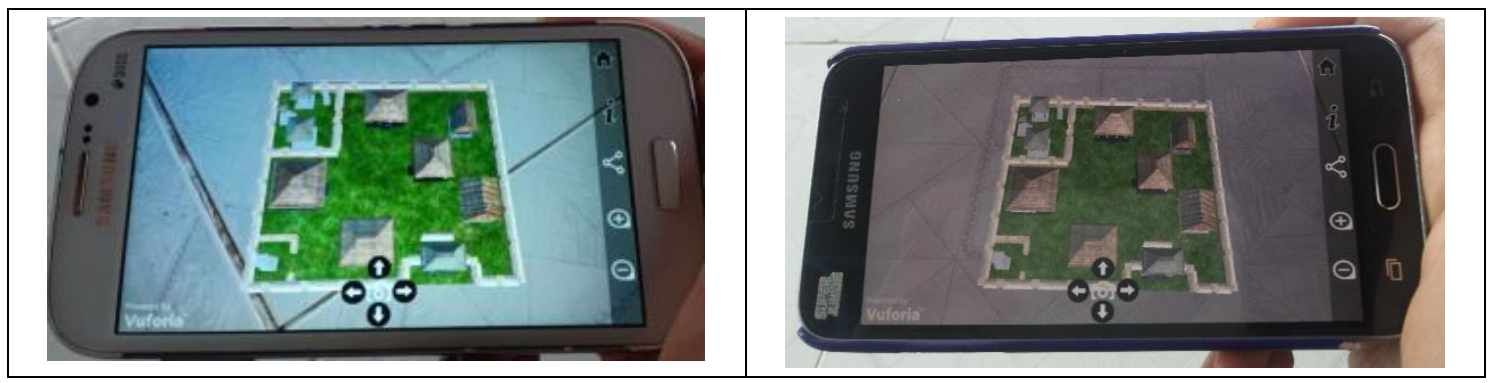

Gambar 7. Uji Coba Scene Tracking Marker

Hasil uji coba menunjukkan proses Tracking Marker berfungsi pada kedua perangkat uji coba, namun terdapat perbedaan waktu tracking. Waktu yang diperlukan untuk masuk ke halaman kamera augmented reality pada kedua perangkat adalah 10 detik. Waktu yang diperlukan untuk menampilkan objek 3-dimensi pada Samsung Galaxy Grand Duos adalah 25 detik, sedangkan pada Samsung Galaxy J3 adalah 18 detik. Perbedaan waktu pada kedua perangkat disebabkan oleh perbedaan spesifikasi.

Pengujian aplikasi juga dilakukan terhadap fitur pendukung aplikasi. Empat fitur yang diujicobakan adalah Info, Rotate, Scale, dan Share. Hasil pengujian fitur aplikasi ditunjukkan pada Tabel 4.

Tabel 4. Hasil Pengujian Fitur Aplikasi

\begin{tabular}{|l|c|c|c|}
\hline \multirow{2}{*}{ Nama Fitur } & \multicolumn{4}{|c|}{ Tampilan pada Perangkat } \\
\cline { 2 - 4 } & Samsung Galaxy Grand Duos & Samsung Galaxy J3 \\
\hline Info & & & \\
\hline Rotate & & & \\
\hline
\end{tabular}




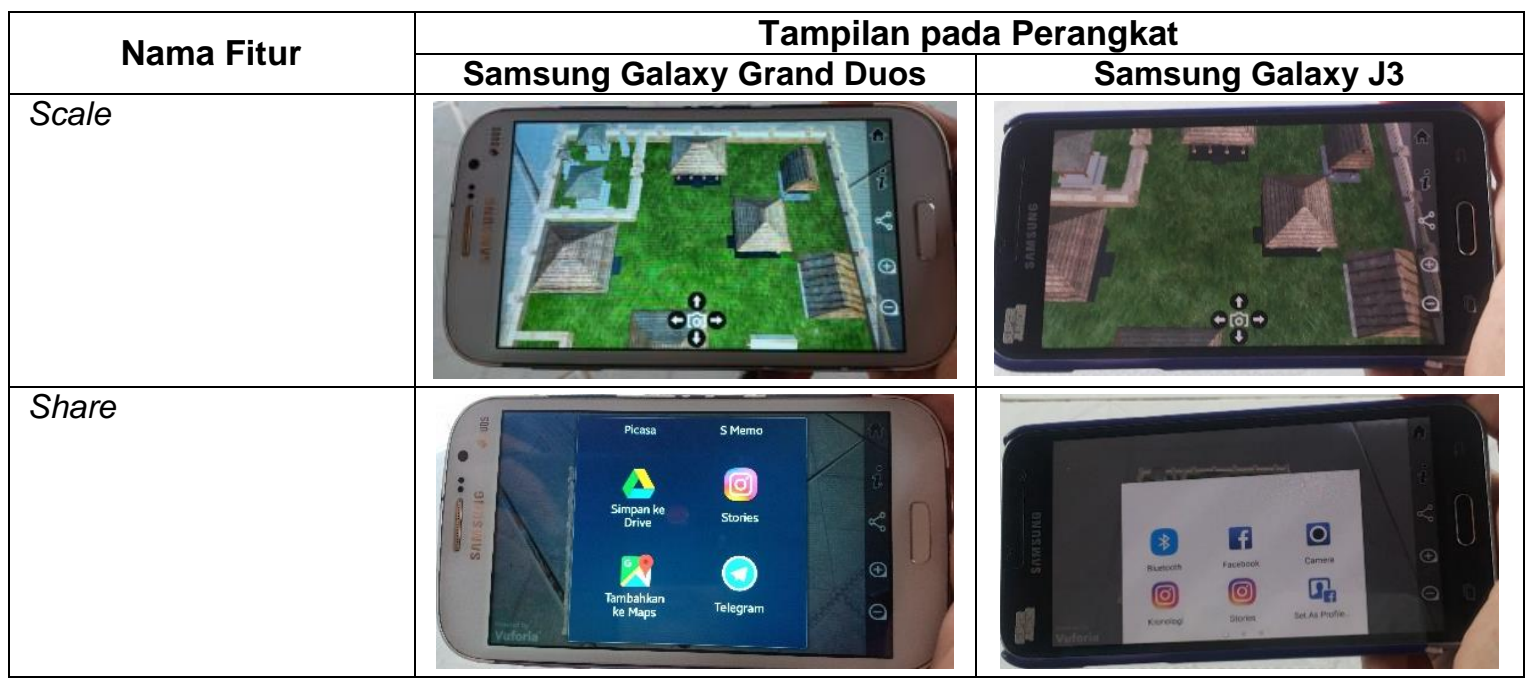

Hasil pengujian pada Tabel 4 menunjukkan semua fitur aplikasi dapat berfungsi dengan baik pada kedua perangkat uji coba.

\subsection{Analisa Hasil}

Pengujian data untuk analisa Aplikasi ARRumahAdat dilakukan dengan menggunakan metode survey dan menggunakan kuesioner sebagai media pengambilan data. Kuesioner diberikan kepada 20 orang responden dengan renatang usia 9-11 tahun yang merupakan anak sekolah dasar di lingkungan Br. Sangut, Carangsari, Petang, Badung. Hasil kuesioner dibagi menjadi beberapa aspek yaitu aspek peningkatan pengetahuan pengguna, aspek kesesuaian proses, dan aspek desain user interface.

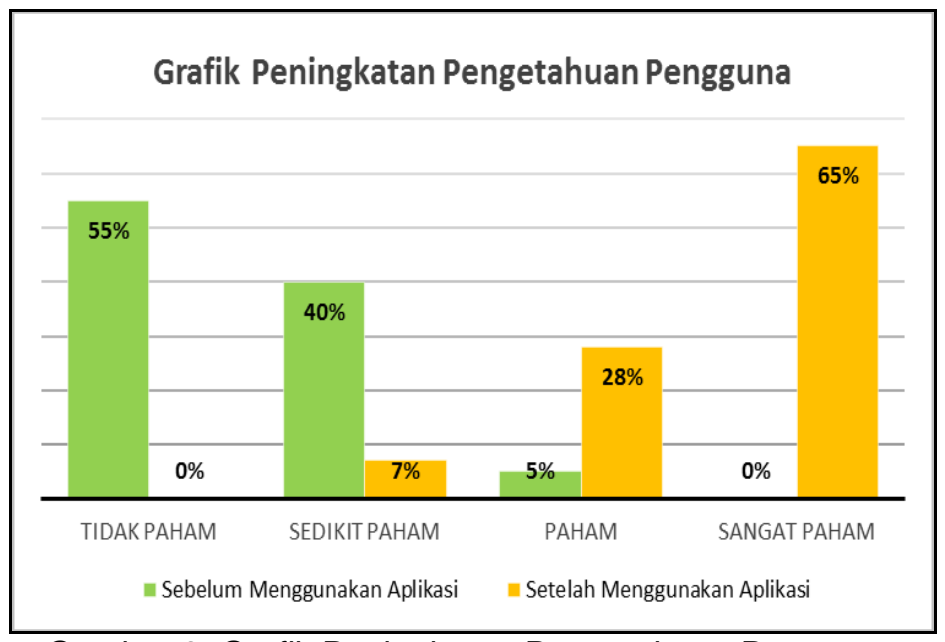

Gambar 8. Grafik Peningkatan Pengetahuan Pengguna

Gambar 8 menunjukkan grafik peningkatan pengetahuan pengguna sebelum dan setelah menggunakan aplikasi menunjukkan bahwa sebelum menggunakan aplikasi, banyak pegguna yang belum mengetahui rumah adat dan setelah menggunakan aplikasi pengguna yang tidak paham menjadi berkurang dengan signifikan. 


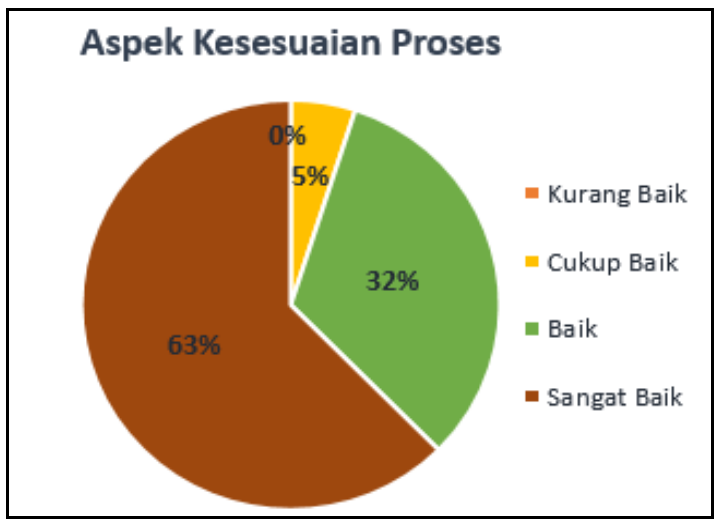

Gambar 9. Aspek Kesesuaian Proses

Gambar 9 menunjukkan aspek kesesuaian proses pada Aplikasi ARRumahAdat memperoleh rata-rata presentase tertinggi dengan respon sangat baik sebesar $63 \%$.

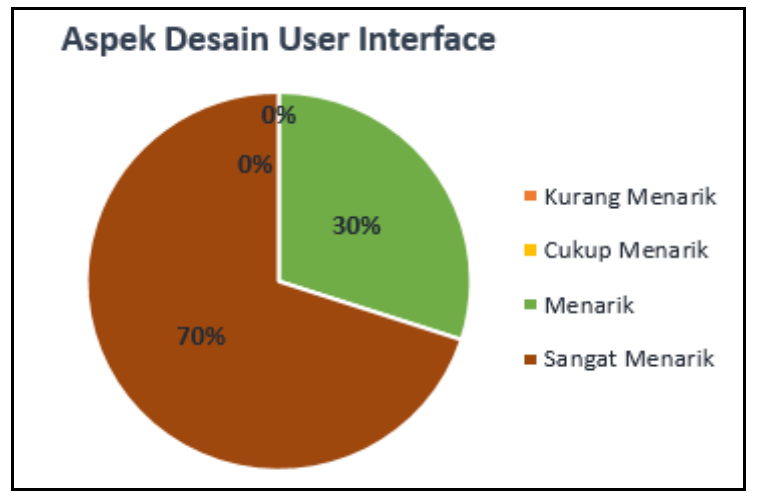

Gambar 10. Aspek Desain User Interface

Gambar 10 menunjukkan aspek desain user interface pada Aplikasi ARRumahAdat memperoleh rata-rata presentase tertinggi pada respon sangat menarik sebesar $70 \%$.

\section{Kesimpulan}

Aplikasi ARRumahAdat yang dikembangkan merupakan aplikasi augmented reality yang bersifat dinamis, sehingga aplikasi dapat berjalan dan menerima penambahan konten tanpa melakukan modifikasi terhadap kode program. Aplikasi berhasil memvisualisasikan 6 rumah adat di Indonesia dalam bentuk objek 3-dimensi, yaitu rumah adat Provinsi Bali, Papua, Banten, Lampung, Sumatera Barat dan Aceh. Aplikasi memiliki 4 scene yaitu Main Menu, Mulai, Panduan, dan Tentang. Fitur yang ada pada aplikasi adalah Info, Rotate, Scale, dan Share. Scene-scene pada aplikasi dapat berfungsi serta tampil secara proporsional menyesuaikan dengan resolusi layar. Fitur-fitur aplikasi berfungsi di kedua perangkat uji coba. Hasil survey yang dilakukan kepada 20 responden menunjukkan Aplikasi ARRumahAdat sangat bermanfaat dalam membantu memahamai rumah adat dengan hasil peningkatan pengetahuan pengguna menjadi $65 \%$ sangat paham.

\section{Daftar Pustaka}

[1] R. P. Yani, "Perubahan Bentuk Arsitektur Rumah Masyarakat Adat dan Pelestarian NilaiNilai Budaya (Studi Kasus Perubahan Tradisi Masyarakat di Kampung Negeri Besar Kecamatan Negeri Besar Kabupaten Way Kanan Tahun 2015)," Universitas Lampung, 2015.

[2] R. Prabowo, T. Listyorini, and A. Jazuli, "Pengenalan Rumah Adat Indonesia Berbasis Augmented Reality dengan Memanfaatkan KTP Sebagai Marker," SNATIF, vol. 2, pp. 51-58, 2011.

[3] I. G. A. Nugraha, I. K. G. Darma Putra, and I. M. Sukarsa, "Rancang Bangun Aplikasi Android AR Museum Bali: Gedung Karangasem dan Gedung Tabanan," Lontar 
Komputer, vol. 7, no. 2, pp. 93-103, 2016.

[4] G. Y. P. Pangestu, N. M. I. M. Mandenni, N. K. D. Rusjayanthi, "Aplikasi Web Augmented Reality Villa," Merpati, vol. 5, no. 1, pp. 29-40, 2017.

[5] A. F. Waruwu, "Augmented Reality Mobile Application of Balinese Hindu Temples: DewataAR," International Journal of Computer Network and Information Security, vol. 7, no. 2, pp. 59-66, 2015.

[6] I. D. G. W. Dhiyatmika, I. K. G. Darma Putra, and N. M. I. M. Mandenni, "Aplikasi Augmented Reality Magic Book Pengenalan Binatang untuk Siswa TK," Lontar Komputer, vol. 6, no. 2, pp. 589-596, 2015.

[7] H. S. Putra, I. N. Piarsa, and I. P. A. E. Pratama, "Design of Balinese Traditional Frame Application using Face Detection Features and Frame Upload Menu Android Based," International Journal of Application or Innovation in Engineering \& Management (IJAIEM), vol. 5, no. 12, pp. 64-70, 2016.

[8] K. D. H. Kusuma, I. K. A. Purnawan, and N. K. D. Rusjayanthi, "Aplikasi Augmented Reality Informasi Corak Endek Bali pada Platform Android," Merpati, vol. 6, no. 1, pp. 25-34, 2018.

[9] D. Kristiani, "Ensiklopedia Negeriku Rumah Adat," Jakarta: Bhuana Ilmu Populer, 2014.

[10] Halim, "Perkembangan Rumah Tradisional Muna," Unity Jurnal Arsitek, vol. 1, no. 2, pp. 68-79, 2011.

[11] N. L. P. N. Ambariani, I. K. A. Purnawan, and K. S .Wibawa, "Aplikasi Pengenalan Jenis Kupu-Kupu Langka Berbasis Augmented Reality," Merpati, vol. 5, no. 3, pp. 207-218, 2017. 